\title{
Diagnosing pubovisceral avulsions: a systematic review of the clinical relevance of a prevalent anatomical defect
}

\author{
Karin Lammers • Jurgen J. Fütterer • Mathias Prokop • \\ Mark E. Vierhout • Kirsten B. Kluivers
}

Received: 28 November 2011 / Accepted: 11 April 2012 / Published online: 12 May 2012

(C) The Author(s) 2012. This article is published with open access at Springerlink.com

\begin{abstract}
The aims of this systematic literature review were to assess whether the detection of pubovisceral avulsions using magnetic resonance (MR) imaging or perineal ultrasonography was clinically relevant in women with pelvic floor dysfunction and to evaluate the relation with anatomy, symptoms, and recurrence after surgery. We performed a systematic literature review using three bibliographical databases (PubMed, Embase, and CINAHL) as data sources. Clinical studies were included in which pubovisceral avulsions were studied in relation to pelvic organ prolapse (POP) stage, pelvic floor symptoms, and/or recurrence of POP after surgery. Ultimately, 21 studies met the inclusion criteria. POP stage and recurrence of POP after surgery were strongly associated with pubovisceral avulsions. Contradictory results were found regarding the relation between pubovisceral avulsions and urinary symptoms and symptoms of anorectal dysfunction. Pubovisceral avulsions, as diagnosed by MR imaging or perineal ultrasonography, are associated with higher stages of POP and recurrence of POP after surgery.
\end{abstract}

Keywords Levator ani · Levator defect · MR imaging · Perineal ultrasonography $\cdot$ Pubovisceral avulsion

\section{Abbreviations \\ POP Pelvic organ prolapse}

K. Lammers $(\varangle) \cdot$ M. E. Vierhout $\cdot$ K. B. Kluivers Department of Obstetrics and Gynaecology (791), Radboud University Nijmegen Medical Centre, P.O. Box 9101, 6500 HB Nijmegen, The Netherlands e-mail: K.Lammers@obgyn.umcn.nl

J. J. Fütterer $\cdot$ M. Prokop

Department of Radiology (667), Radboud University

Nijmegen Medical Centre,

Nijmegen, The Netherlands

$\begin{array}{ll}\text { UI } & \text { Urinary incontinence } \\ \text { MR } & \text { Magnetic resonance } \\ \text { 3-D } & \text { Three-dimensional } \\ \text { 4-D } & \text { Four-dimensional (3-D + temporal information) } \\ \text { POP-Q } & \text { Pelvic Organ Prolapse Quantification } \\ \text { TUI } & \text { Tomographic ultrasound imaging } \\ \text { SUI } & \text { Stress urinary incontinence } \\ \text { RI } & \text { Rectal intussusception } \\ \text { FI } & \text { Fecal incontinence } \\ \text { TRUDIL } & \underline{\text { Translabial 3D-ultrasonography for diagnosing }} \\ & \underline{\text { levator defects }}\end{array}$

\section{Introduction}

Pelvic floor dysfunction is an often used term that covers many different conditions including pelvic organ prolapse (POP), urinary incontinence (UI), and anorectal dysfunction. POP has a significant negative impact on women's quality of life, affects physical well-being, psychological and sexual functioning, and causes occupational and social restraints [1]. Up to $20 \%$ of the general female population will have symptoms of POP and/or UI significant enough to require surgery $[2-5]$. Both conditions often occur concurrently: up to $40 \%$ of POP patients have preoperative concomitant UI $[1,6]$. Of the women undergoing POP surgery, almost one third will develop postoperative recurrence for which additional surgery is needed. The highest recurrence rates are reported in the anterior vaginal compartment $[2,7]$. Important risk factors for the development of POP are a family history of POP and vaginal delivery [8], and over the past decade levator ani muscle injury emerged as a major contributing factor in POP pathophysiology. This type of injury is only observed in women who have given birth vaginally or 
have at least entered the second stage of labor. Risk factors for levator ani muscle injury are forceps delivery, length of second stage of labor, and large fetal head circumference [9-12]. Besides being associated with an increased risk of POP, levator ani muscle injury has been reported to lead to an increased risk of recurrence after POP surgery [13, 14].

The prevalence of levator ani muscle injury is reported to be up to $36 \%$ in vaginally parous women and presents as a detachment, i.e., avulsion, of the pubovisceral component of the levator ani muscle from the pubis [15-17]. These pubovisceral avulsions can be observed as a complete loss of connection to the pubis or as a partial detachment with apparent loss of muscle bulk, both either unilateral or bilateral. Pubovisceral avulsions can be visualized using magnetic resonance (MR) imaging [13] or three-dimensional (3D) perineal ultrasonography [18]. MR imaging is a noninvasive diagnostic tool that allows for detailed evaluation of all soft tissue structures of the pelvic support system. Perineal ultrasonography is increasingly used in urogynecology and provides four-dimensional (4-D, i.e., 3-D +temporal information) assessment of the pelvic floor during routine clinical practice. Both MR imaging and perineal ultrasonography require post-processing of the obtained image data, for which significant training is needed. Which of these diagnostic methods is best for diagnosing pubovisceral avulsions is still under investigation.

Various studies have been conducted with regard to pubovisceral avulsions and the associated risks and specific symptoms. The aims of this systematic literature review were to assess whether the detection of pubovisceral avulsions by MR imaging or perineal ultrasonography was clinically relevant in women with pelvic floor dysfunction and to evaluate if there was a relation with anatomy and symptoms.

\section{Materials and methods}

A systematic literature search was performed by a clinical researcher (KL) and a senior librarian. The electronic databases PubMed, Embase, and CINAHL were searched from inception up to 27 September 2011. The search and selection of the literature were restricted to publications written in Western languages. To capture all relevant articles on the clinical relevance of pubovisceral avulsions, as diagnosed by MR imaging or perineal ultrasonography, we chose the following strategy: search term combinations were adapted for each database and consisted of Medical Subject Headings (MeSH), thesaurus terms and CINAHL headings, text words and word variations for the terms "pelvic floor," "MR imaging," "ultrasonography," and "physical examination." The entire strings of search terms are depicted in Appendices 1, 2 , and 3. Due to the large variability of terms that indicate pubovisceral avulsions, e.g., detachment, disconnection, tearing off, and severing, we did not attempt to include the corresponding terms in the search strategy but used this as an inclusion criterion. Hereby, the initial search was as sensitive as possible.

Articles identified by the literature search were included in our systematic review in case they reported on pubovisceral avulsions diagnosed by at least one of the two diagnostic methods: MR imaging and perineal ultrasonography. Articles were included if they concerned clinical studies that provided data on POP status, pelvic floor symptoms, or recurrence of POP after surgery. Pelvic floor symptoms had to be documented using standardized questions or validated (quality of life) questionnaires. Recurrence of POP after surgery and POP status had to be documented with a standardized method, such as the Pelvic Organ Prolapse Quantification (POP-Q) [19] or Baden-Walker system, or stated as number of reoperations. Letters, commentaries, and editorial notes were excluded.

All studies were evaluated by title and abstract according to the inclusion and exclusion criteria by KL. If necessary, full text articles were evaluated. After this preselection, a final decision on inclusion or exclusion was made in consensus with an experienced pelvic floor specialist (KK). Reference lists of relevant retrieved studies were crosschecked to identify additional studies that had been overlooked in the database search.

The full text articles were evaluated to collect data on study design, aim of the study, sample size, study population, control group, parity, age, diagnostic method(s), POP staging, previous prolapse surgeries, number of reoperations, and the method(s) of pelvic floor symptom assessment.

To report pubovisceral avulsions, scoring systems have previously been developed by other research groups. In MR imaging, defect severity is scored in both muscle sides separately, ranging from 0 (no defect) to 3 (complete muscle loss). A summed score for the two sides (0-6) can then be assigned and grouped as no defect (0), minor defect (1-3), or major defect (4-6, or a unilateral score of 3) [20]. For perineal ultrasonography, the integrity of the pubovisceral muscle is evaluated in the axial plane using multislice imaging, i.e., tomographic ultrasound imaging (TUI). A set of eight tomographic slices are evaluated at intervals of $2.5 \mathrm{~mm}$, in which both muscle sides are scored separately, resulting in a defect score ranging from 0 (no defect) to 16 (complete bilateral avulsion). A complete avulsion is diagnosed if the reference slice, i.e., the slice that represents the plane of minimum hiatal dimensions, as well as the two slices immediately cranial to this plane show an avulsion. Partial avulsion is diagnosed when any of the slices are abnormal, without the patient being classified as having a complete avulsion [21, 22]. 


\section{Results}

The PubMed search revealed 1,844 articles. The Embase and CINAHL searches found an additional 1,171 and 119 articles, respectively. In total, 3,134 articles were checked for eligibility. No additional studies were identified by cross-checking reference lists. A flowchart of the selection procedure is presented in Fig. 1. Eight studies reported on detection of pubovisceral avulsion using MR imaging [13, 15, 23-28]. Twelve studies used perineal ultrasonography as the diagnostic method [14, 17, 22, 29-37]. Apart from these 20 studies that used one diagnostic method for the evaluation of pubovisceral avulsions, we identified 4 studies that compared the use of different diagnostic methods. Of these, two studies compared perineal ultrasonography with palpation of the pubovisceral muscle defect $[38,39]$. In both studies, the detection of pubovisceral avulsions was the outcome measure of interest. One study compared MR imaging with palpation [40] and one study compared ultrasonography with MR imaging [41]. In these studies, the objective was to determine the agreement in the detection of abnormalities in the pubovisceral muscle. Of the latter four studies that evaluated two diagnostic methods, only one compared their results with our outcomes of interest [38] and was therefore the only article included in this review that used two different diagnostic methods. Ultimately, 21 articles could be included in our systematic literature review. Study designs, group characteristics, diagnostic methods, and outcome measures are summarized in Table $1[13-15,17,22-38]$. Apart from two studies published in 2003 [15, 23], all other articles have been published after 2005.

Tables 2, 3, 4 and 5 provide an overview of the studies assessing pubovisceral avulsions in relation to urinary symptoms, symptoms of anorectal dysfunction, POP anatomy and symptoms, and recurrence of POP after surgery, respectively.

Studies on the relation between urinary symptoms and pubovisceral avulsions yielded contradictory results (Table 2). DeLancey et al. [15] found that the prevalence of pubovisceral avulsions was more than twice as high in primiparous women with stress urinary incontinence (SUI) than in primiparous women without SUI. Dietz et al. reported that women with urogynecological complaints and pubovisceral avulsions more often suffered from urinary frequency [17] and voiding dysfunction [33]. They also found that women over the age of 50 were less likely to suffer from SUI [33]. Morgan et al. [26] studied women with POP $\geq$ stage II and found that women with major defects had the lowest risk of SUI symptoms, while this risk was the highest in women with minor defects. Heilbrun et al. [24] reported no association between complaints of (S)UI and levator ani defect status.

Two of the available studies on anorectal dysfunction found that women with major or complete pubovisceral avulsions were more likely to report symptoms of anorectal dysfunction than women with minor or no avulsions (Table 3). This association was found in women who had suffered an anal sphincter tear during delivery [24] and "older" women [25]. For women with POP $\geq$ stage II and for women with urogynecological complaints, i.e., women with symptoms of lower urinary tract and pelvic floor dysfunction, no significant relation between symptoms of anorectal dysfunction and pubovisceral avulsions could be found [27, 30]. Rodrigo et al. [36] reported that the prevalence of rectal intussusception (RI) was higher among women with pubovisceral avulsions.

Eleven studies reported on POP anatomy and symptoms in relation to pubovisceral avulsions. All studies used the POP-Q system to stage POP. Except for Morgan et al. [28], who did not find a difference in anterior, apical, and posterior POP-Q data between women with and without major levator defects, all other ten studies did find a significant relation with women with pubovisceral avulsions reporting POP more often (Table 4). This relation was strongest with regard to the anterior $[14,17,22$, $24,29,31,38]$ and central vaginal compartment $[14,17$, $29,31]$, but was less apparent for the posterior vaginal compartment [24, 29].

Table 5 shows that recurrence of POP after surgery was related to pubovisceral avulsions in all available studies on the subject $[28,32,34,35,37]$. This association was merely seen in women with major pubovisceral avulsions as diagnosed by MR imaging or in women with a complete avulsion according to perineal ultrasonography. Wong et al. [37] have reported on the recurrence of POP in women with pubovisceral avulsions following anterior vaginal mesh surgery.

\section{Discussion}

In this systematic literature review, we assessed the clinical relevance of diagnosing pubovisceral avulsions in women with pelvic floor dysfunction. Diagnostic methods of interest were MR imaging and perineal ultrasonography. The presence of pubovisceral avulsions was shown to be relevant with respect to POP symptoms and POP stage, especially in the anterior and central compartment. Recurrence of POP after surgery was also related to avulsions according to the available studies. There was no clear relation between pubovisceral avulsions and SUI, but in this respect, there might be a difference between minor and major defects [26]. Studies with regard to the relation between symptoms of 


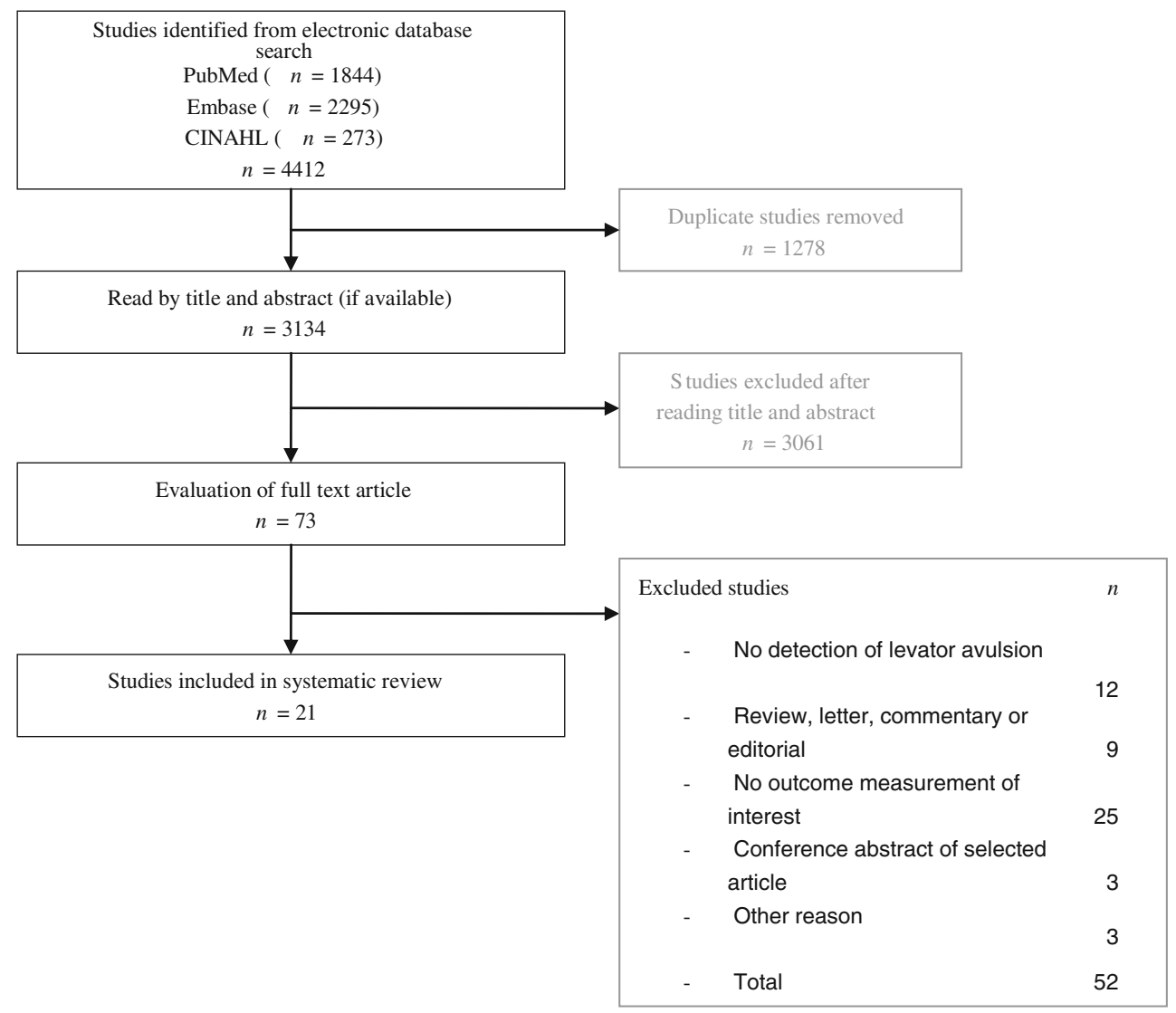

Fig. 1 Selection process of studies included in the systematic review. $n$ number of articles

anorectal dysfunction and pubovisceral avulsions yielded contradictory results.

Even though it has long been recognized that the levator ani muscle plays a critical role in pelvic organ support, in what way pregnancy and/or childbirth injure the pelvic floor has not been proven conclusively. Pelvic floor injury might be caused by compression, stretching or tearing of nerves, muscles, and/or connective tissue [42, 43]. Evaluation of the importance of muscle integrity has gone through an exponential growth over the past decade with the assessment of pubovisceral avulsions initially being performed using MR imaging. Therefore, this diagnostic method became the reference standard. The research group of Professor DeLancey was the first to standardize the evaluation of MR images [44]. However, nowadays a growing amount of studies use perineal ultrasonography to assess pubovisceral muscle integrity as this diagnostic method has the advantage over MR imaging of easier implementation in routine clinical care together with the benefits of significantly lower cost and superior availability. The standardization of perineal ultrasonography when evaluating pubovisceral avulsions was performed under the supervision of Professor Dietz [31]. Approximately half of the studies in this review focused on using MR imaging to detect pubovisceral avulsions while a slightly higher number of studies used perineal ultrasonography.

There was a notable variance in the naming for the subdivision of the levator ani muscle of interest for this review. In 2004, Kearney et al. [45] performed a literature search on the various descriptions and terminology for this muscle. They found that even though there was a great diversity regarding the terms chosen in the available literature, the number of origin and insertion pairs was relatively consistent among authors. Overall, the levator ani muscle comprises three subdivisions, namely, the iliococcygeal, puborectal, and pubovisceral muscles. The pubovisceral muscle includes the puboanal, puboperineal, and pubovaginal muscles and, together with the puborectal muscle, originates from the pubis [15]. Another frequently used term for the pubovisceral muscle is pubococcygeus muscle; however, this implies a connection between the pubis and coccyx while in fact the muscle originates from the pubis and inserts into the wall of the vagina and anorectum. It is thus our belief that pubovisceral muscle is the correct term to be used.

We had some difficulty to decide on the inclusion of one study by Adekanmi et al. [46]. The muscle injuries that were evaluated differed from injuries as described in all other studies with a distinction being made by Adekanmi et al. 


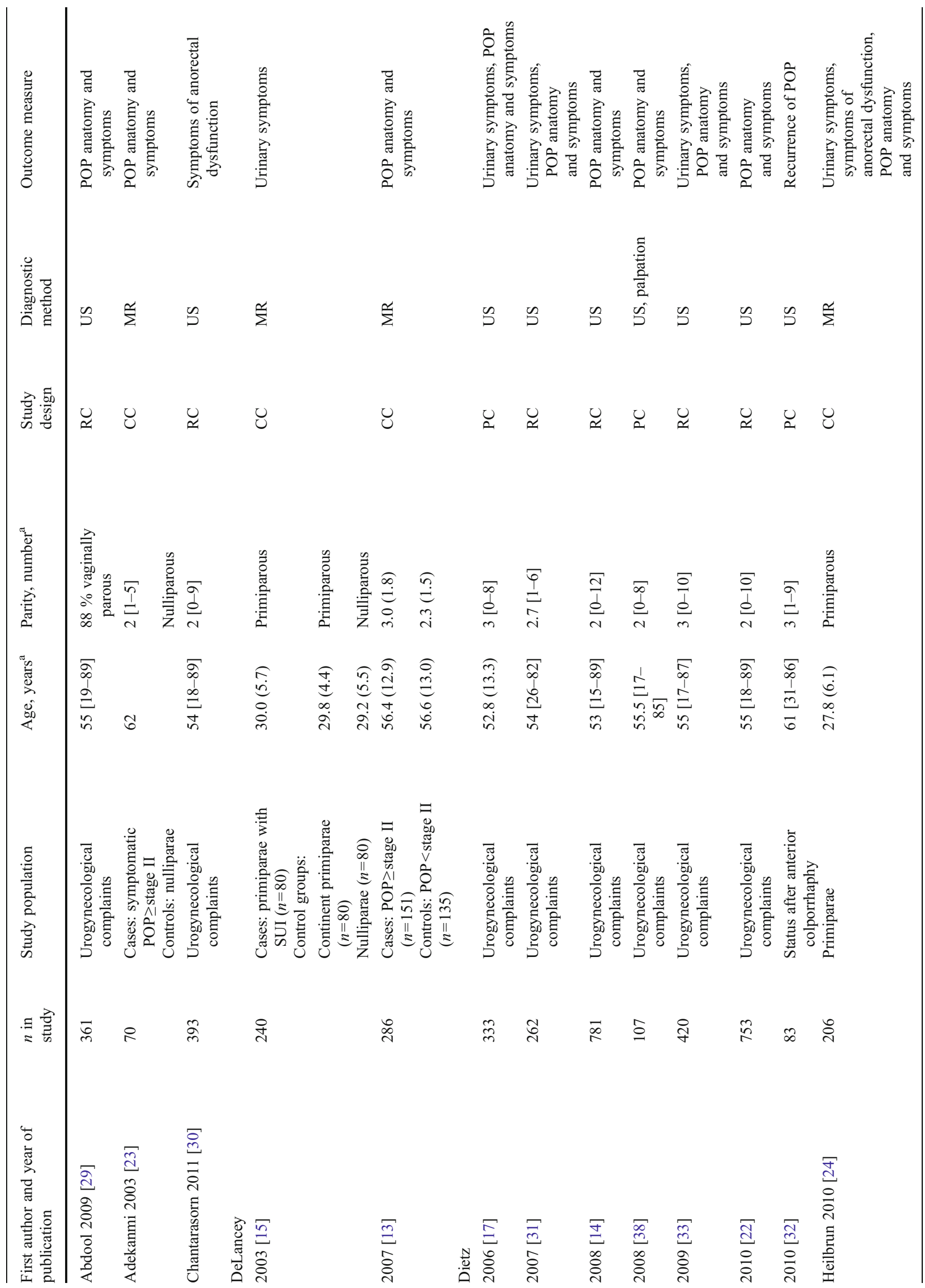




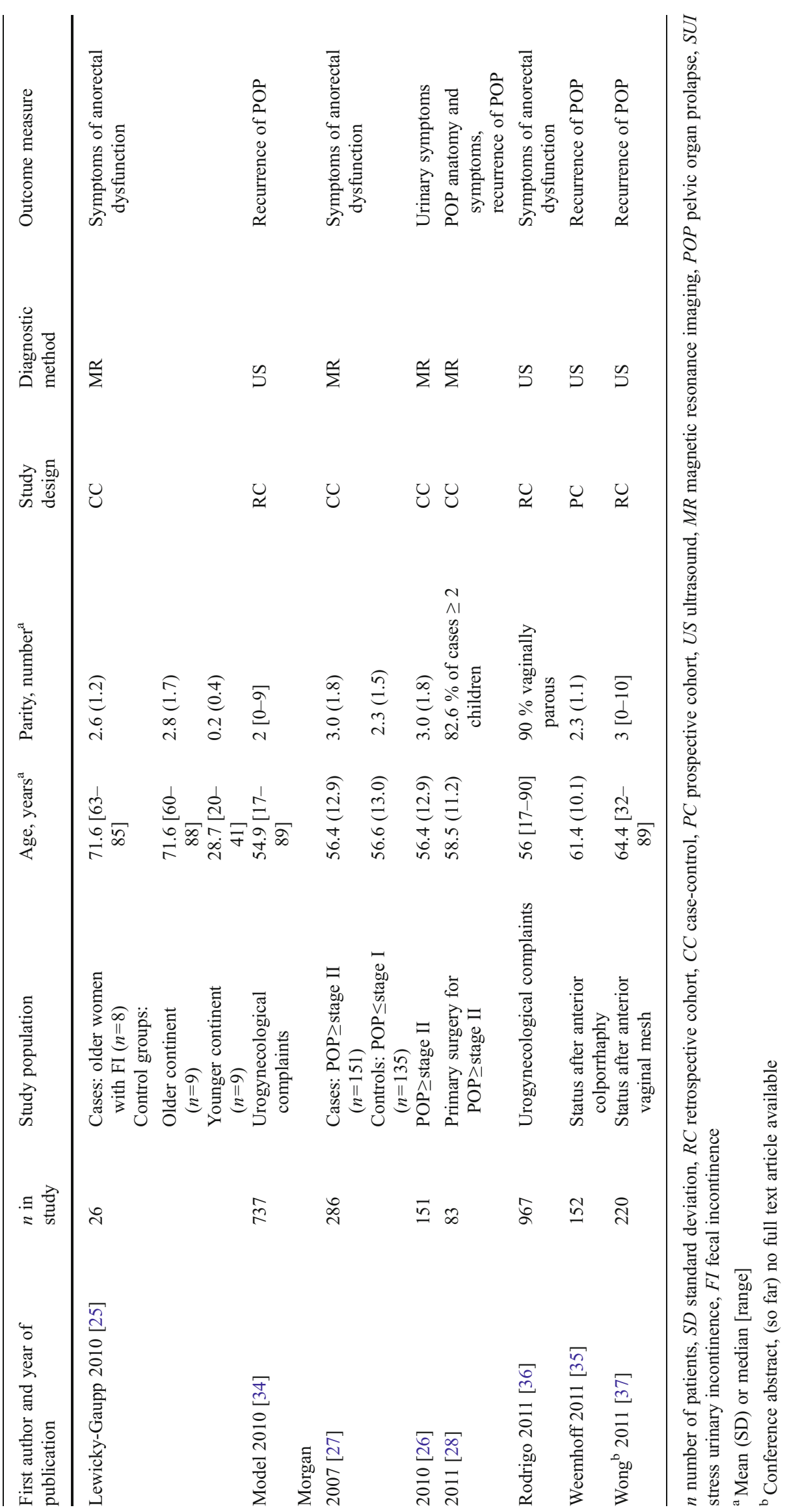


Table 2 Urinary symptoms in women assessed for pubovisceral avulsions $n$ number of patients, $(S) U I$

(stress) urinary incontinence, $p$ value $p$ value for difference between avulsion and outcome measure assessed, USI urodynamic stress incontinence, MESA medical, epidemiological, and social aspects of aging

\begin{tabular}{|c|c|c|c|c|}
\hline $\begin{array}{l}\text { First } \\
\text { author }\end{array}$ & $\begin{array}{l}n \text { with levator } \\
\text { avulsion }\end{array}$ & & $\begin{array}{l}\text { Percentage of women of } \\
\text { study population with } \\
\text { levator avulsion }\end{array}$ & Conclusion \\
\hline $\begin{array}{l}\text { DeLancey } \\
{[15]}\end{array}$ & $\begin{array}{l}\text { Cases: } \\
\text { Control } \\
\text { groups: } \\
\text { Non-SUI } \\
\text { primiparae } \\
\text { Nulliparae }\end{array}$ & 23 & $\begin{array}{l}11 \% \\
0 \%\end{array}$ & $\begin{array}{l}\text { Primiparous women with SUI were twice } \\
\text { as likely to have a muscle abnormality } \\
\text { than primiparae without SUI. No } \\
\text { avulsions were identified in nulliparous } \\
\text { women }\end{array}$ \\
\hline Dietz [17] & Complete & 46 & $14 \%$ & $\begin{array}{l}\text { No association was found between } \\
\text { complete avulsion and urodynamic } \\
\text { findings or symptoms of bladder } \\
\text { dysfunction except for frequency } \\
(p=0.02)\end{array}$ \\
\hline Dietz [31] & Complete & 50 & $19 \%$ & $\begin{array}{l}\text { Sixty-two percent of women with } \\
\text { complete avulsions complained of SUI. } \\
\text { Defect score was significantly higher in } \\
\text { women with symptoms of urinary } \\
\text { frequency }(p=0.05)\end{array}$ \\
\hline Dietz [33] & Complete & 104 & $25 \%$ & $\begin{array}{l}\text { Women with complete avulsions } \\
\text { were less likely to suffer from } \\
\text { SUI }(p<0.001) \text { and USI }(p=0.065) \text {, } \\
\text { but more likely to show signs of } \\
\text { voiding dysfunction }(p=0.005)\end{array}$ \\
\hline $\begin{array}{l}\text { Heilbrun } \\
\text { [24] }\end{array}$ & Major & 20 & $10 \%$ & $\begin{array}{l}\text { There was no relation between major } \\
\text { avulsion and (S)UI based on MESA } \\
\text { compared to women with minor or no } \\
\text { avulsion }\end{array}$ \\
\hline $\begin{array}{c}\text { Morgan } \\
{[26]}\end{array}$ & $\begin{array}{l}\text { Major } \\
\text { Minor }\end{array}$ & $\begin{array}{l}83 \\
24\end{array}$ & $\begin{array}{l}55 \% \\
16 \%\end{array}$ & $\begin{array}{l}\text { SUI symptoms were least present in } \\
\text { women with major avulsions and most } \\
\text { frequently reported by women } \\
\text { with minor avulsions }\end{array}$ \\
\hline
\end{tabular}

between central and lateral (endopelvic) fascial defects as well as changes in vaginal configuration after surgery. Based on subsequently published literature and correspondence with the authors, we came to the conclusion that the researchers had not studied pubovisceral avulsions as included in this review. The paper was therefore excluded.

The present review showed that the relation between POP and pubovisceral avulsions is eminent as all but one paper [28] found a significant difference in POP incidence (Table 4). This relation was strongest in the compartments with highest recurrence rates after POP surgery, namely, the anterior and central vaginal compartment. DeLancey et al. [13] were the only researchers to perform a case-control study with group matching for POP status in which, after multivariable regression, avulsion was still identified as an independent risk factor for POP. We were not able to further assess the correlation between avulsions and POP stage, POP surgeries, and $P O P$ recurrences from the accumulated data in this review. However, as up to $30 \%$ of POP surgeries are currently performed due to relapse of POP [2], pubovisceral avulsions seem clinically relevant as an independent risk factor for POP. It has been suggested that women with pubovisceral avulsions might benefit from primary vaginal mesh surgery [47, 48]. However, Wong et al. [37] found that mesh implementation in these women did not fully compensate for the effect of pubovisceral avulsions on recurrence rates. Evaluating pubovisceral muscle integrity in appropriate clinical POP outcome studies will be needed to further lead the way, especially with regard to different strategies in surgical repair of various POP stages. Which diagnostic method, MR imaging or perineal ultrasonography, should be used remains to be assessed as well [49].

While the association between urinary symptoms and childbirth is beyond dispute [50], this is presumably not directly related to pubovisceral avulsions, since available studies have shown contradictory results. Women with pubovisceral avulsions were less likely to suffer from SUI (subjective and/or objective as confirmed by urodynamics) [33]. When pubovisceral avulsions were divided into major and minor avulsions, it was found that women with major defects are less likely and women with minor defects are more likely to have lower urinary tract symptoms [26]. The lack of a clear association between avulsions and SUI might be due to the fact that these avulsions do not seem to affect urethral mobility as much as they affect bladder support [51, 
Table 3 Symptoms of anorectal dysfunction and the relation with pubovisceral avulsions $n$ number of patients, $O I$ older incontinent, $O C$ older continent, $Y C$ young continent, $F I$ fecal incontinence, FISI Fecal Incontinence Severity Index, $p$ value $p$ value for difference between avulsion and outcome measure assessed, $P O P$ pelvic organ prolapse, $R I$ rectal intussusception

\begin{tabular}{|c|c|c|c|c|}
\hline First author & $\begin{array}{l}n \text { with levatc } \\
\text { avulsion }\end{array}$ & & $\begin{array}{l}\text { Percentage of women of } \\
\text { study population with } \\
\text { levator avulsion }\end{array}$ & Conclusion \\
\hline $\begin{array}{l}\text { Chantarasorn } \\
{[30]}\end{array}$ & $\begin{array}{l}\text { Complete } \\
\text { bilateral } \\
\text { Complete } \\
\text { unilateral }\end{array}$ & 38 & $\begin{array}{l}10 \% \\
10 \%\end{array}$ & $\begin{array}{l}\text { Both unilateral and bilateral } \\
\text { complete avulsions were } \\
\text { not associated with FI, fecal } \\
\text { urgency, or flatus incontinence }\end{array}$ \\
\hline $\begin{array}{l}\text { Heilbrun } \\
{[24]}\end{array}$ & Major & 20 & $10 \%$ & $\begin{array}{l}\text { Women with major avulsions } \\
\text { had a higher prevalence of FI } \\
\text { based on FISI questionnaire } \\
(p=0.006) \text { compared to women } \\
\text { with no or minor avulsions }\end{array}$ \\
\hline $\begin{array}{l}\text { Lewicky- } \\
\text { Gaupp [25] }\end{array}$ & $\begin{array}{l}\mathrm{OI} \\
\mathrm{OC} \\
\mathrm{YC} \\
\text { Overall }\end{array}$ & $\begin{array}{l}6 \\
2 \\
1 \\
9\end{array}$ & $\begin{array}{l}75 \% \\
22 \% \\
11 \% \\
35 \%\end{array}$ & $\begin{array}{l}\text { Older women with FI were more } \\
\text { likely to have avulsions than } \\
\text { women without FI }\end{array}$ \\
\hline Morgan [27] & $\begin{array}{l}\text { Cases: } \\
\text { Major } \\
\text { Minor } \\
\text { Controls: } \\
\text { Major } \\
\text { Minor }\end{array}$ & $\begin{array}{l}21 \\
30\end{array}$ & $\begin{array}{l}55 \% \\
16 \%\end{array}$ & $\begin{array}{l}\text { There was no relation between } \\
\text { levator ani defect status and } \\
\text { symptom severity of anal } \\
\text { incontinence and difficult } \\
\text { defecation among women } \\
\text { with POP }\end{array}$ \\
\hline Rodrigo [36] & Complete & 209 & $22 \%$ & $\begin{array}{l}\text { Levator ani avulsion was more } \\
\text { common among women with RI } \\
(p=0.003) \text {. On multivariable } \\
\text { analysis, there was no independent } \\
\text { effect of avulsion }\end{array}$ \\
\hline
\end{tabular}

52]. Moreover, Morgan et al. [28] suggested that damage to the pudendal nerve could explain the difference in frequency of urinary symptoms between major and minor defects. They proposed that with a minor injury the preservation of one side of the muscle or parts of both sides can result in an asymmetry that alters reflexive responses of the urethra, bladder, and pelvic floor leading to symptom exacerbation, while a complete injury may be symmetrical leading to the absence of a motor and sensory reflex and therefore potentially having a less dramatic effect on symptoms. Electromyographic research to support this hypothesis is currently lacking.

The fact that pubovisceral avulsions are caused by vaginal delivery is beyond question and the same accounts for the occurrence of sphincter tears due to vaginal delivery. As the latter association is found to be related to symptoms of anorectal dysfunction, e.g., fecal incontinence (FI), together with the similar etiology of pubovisceral avulsions and sphincter tears, we expected a relation between symptoms of anorectal dysfunction and pubovisceral avulsions. This expectation is strengthened by the finding of Heilbrun et al. [24] that women with major levator defects have a higher prevalence of anal sphincter tears. Moreover, Lewicky-Gaupp et al. [25] found that older women with FI were more likely to have levator defects than women without FI (both younger and older) and that this association remained significant after correcting for external anal sphincter tears. Rodrigo et al. [36] reported a higher prevalence of RI among a group of women with pubovisceral avulsions. After multivariable analysis, this relation came on the account of hiatal area size on Valsalva and was not the effect of avulsions per se.

A limitation of this review was the heterogeneity of the available studies. Due to the variation in diagnostic methods used, study populations included, and outcome measures assessed, it was not possible to pool the available data into reliable relative risk factors for pubovisceral avulsions. To perform a patient-specific risk analysis and to ultimately individualize therapy for POP, it is our recommendation to evaluate the integrity of the pubovisceral muscle in those women who are most affected by the consequences of pubovisceral avulsions, i.e., women visiting tertiary urogynecological clinics. Therefore, both standardized questionnaires regarding symptoms of pelvic floor dysfunction and clinical examination, e.g., POP-Q, should be registered in this population.

Another limitation was that all studies but one [35] on perineal ultrasonography are coauthored by Professor Dietz (Sydney, Australia). With regard to the technique of MR imaging, Professor DeLancey (Ann Arbor, MI, USA) coauthored six of eight of the included studies. Both researchers are renowned experts within their field, but external validation therefore seems relevant and is awaiting. Little data are 
Table 4 POP anatomy and symptoms in women assessed for pubovisceral avulsions

\begin{tabular}{|c|c|c|c|c|}
\hline $\begin{array}{l}\text { First } \\
\text { author }\end{array}$ & \multicolumn{2}{|c|}{$\begin{array}{l}n \text { with levator } \\
\text { avulsion }\end{array}$} & $\begin{array}{l}\text { Percentage of women of } \\
\text { study population with } \\
\text { levator avulsion }\end{array}$ & Conclusion \\
\hline $\begin{array}{l}\text { Abdool } \\
\text { [29] }\end{array}$ & $\begin{array}{l}\text { Bilateral } \\
\text { Unilateral }\end{array}$ & $\begin{array}{l}31 \\
45\end{array}$ & $\begin{array}{l}9 \% \\
12 \%\end{array}$ & $\begin{array}{l}\text { Cystocele and rectocele (on POP-Q) were } \\
\text { associated with both unilateral and } \\
\text { bilateral avulsion. Uterine prolapse } \\
\text { was only related to bilateral avulsion }\end{array}$ \\
\hline $\begin{array}{l}\text { Adekanmi } \\
\text { [23] }\end{array}$ & $\begin{array}{l}\text { Cases: } \\
\text { Partial } \\
\text { Complete } \\
\text { Controls }\end{array}$ & $\begin{array}{l}18 \\
21 \\
0\end{array}$ & $\begin{array}{l}26 \% \\
30 \% \\
0 \%\end{array}$ & $\begin{array}{l}\text { Women with symptomatic } \mathrm{POP} \geq \text { stage II } \\
\text { showed in } 56 \% \text { of the cases a partial } \\
\text { or complete avulsion. No avulsions } \\
\text { were identified in nulliparous women }\end{array}$ \\
\hline $\begin{array}{l}\text { DeLancey } \\
\text { [13] }\end{array}$ & $\begin{array}{l}\text { Cases: } \\
\text { Major } \\
\text { Minor } \\
\text { Controls: } \\
\text { Major } \\
\text { Minor }\end{array}$ & $\begin{array}{l}21 \\
30\end{array}$ & $\begin{array}{l}16 \% \\
22 \%\end{array}$ & $\begin{array}{l}\text { Major avulsions were statistically } \\
\text { significant related to POP status ( } p< \\
0.001) \text { and associated with an adjusted } \\
\text { OR of } 7.3 \text { (95\% CI 3.9-13.6) }\end{array}$ \\
\hline Dietz [14] & Complete & 181 & $23 \%$ & $\begin{array}{l}\text { Women with complete avulsions were } \\
\text { twice as likely to have significant POP, } \\
\text { especially cystocele and uterine prolapse }\end{array}$ \\
\hline Dietz [38] & Complete & 21 & $20 \%$ & $\begin{array}{l}\text { Women with a palpated avulsion showed } \\
\text { more cystocele descent both on ultrasound } \\
\text { and on POP-Q }\end{array}$ \\
\hline Dietz [17] & Complete & 46 & $14 \%$ & $\begin{array}{l}\text { Women with complete avulsions had higher } \\
\text { grades of POP of the anterior and central } \\
\text { compartment. There was no association } \\
\text { between complete avulsion and POP } \\
\text { symptoms }\end{array}$ \\
\hline Dietz [31] & Complete & 50 & $19 \%$ & $\begin{array}{l}\text { Defect score was associated with cystocele } \\
\text { and uterine prolapse and POP symptoms }\end{array}$ \\
\hline Dietz [33] & Complete & 104 & $25 \%$ & $\begin{array}{l}\text { Women with a complete avulsion were more } \\
\text { likely to have POP of the anterior } \\
\text { compartment }(p<0.001)\end{array}$ \\
\hline Dietz [22] & Complete & 226 & $30 \%$ & $\begin{array}{l}\text { A complete avulsion was strongly } \\
\text { associated with symptoms of POP, } \\
\text { significant POP on clinical assessment, } \\
\text { and bladder descent on perineal } \\
\text { ultrasonography (all } p<0.001 \text { ) }\end{array}$ \\
\hline $\begin{array}{l}\text { Heilbrun } \\
{[24]}\end{array}$ & Major & 20 & $10 \%$ & $\begin{array}{l}\text { POP-Q points Ba and Bp were more often at } \\
\text { or below the hymen in women with major } \\
\text { avulsions compared to women with no or } \\
\text { minor avulsions }\end{array}$ \\
\hline $\begin{array}{c}\text { Morgan } \\
{[28]}\end{array}$ & Major & 46 & $55 \%$ & $\begin{array}{l}\text { There was no difference in preoperative } \\
\text { anterior, apical, and posterior POP-Q } \\
\text { data between women with and without } \\
\text { a major avulsion }\end{array}$ \\
\hline
\end{tabular}

$P O P$ pelvic organ prolapse, $n$ number of patients, $P O P-Q$ Pelvic Organ Prolapse Quantification, $p$ value $p$ value for difference between avulsion and outcome measure assessed, $O R$ odds ratio, $95 \%$ CI $95 \%$ confidence interval, $B a$ and $B p$ most descended edge of anterior and posterior vaginal wall, respectively, relative to the hymen currently available on agreement between MR imaging and perineal ultrasonography in the evaluation of pubovisceral avulsions. Regarding this, Zhuang et al. [41] are the first to compare ultrasonography to MR imaging. They reported a substantial agreement for both agreement between methods (Cohen's kappa=0.79) and for agreement regarding the extent of the avulsion (Cohen's kappa=0.65). To further evaluate the agreement between MR imaging and perineal ultrasonography with regard to pubovisceral avulsions and to obtain the level of agreement between observers, the translabial 3D-ultrasonography for diagnosing levator defects (TRUDIL) study is currently being performed in the Netherlands [49].

Besides visualizing pubovisceral avulsions, these muscle defects can also be palpated. Using palpation, a pubovisceral avulsion is diagnosed if there is a detachment of the pubovisceral muscle from its insertion on the pubis [38]. Palpation can be easily incorporated in the standard 
Table 5 Recurrence of POP after surgery in relation to pubovisceral avulsions

\begin{tabular}{|c|c|c|c|c|c|}
\hline $\begin{array}{l}\text { First } \\
\text { author }\end{array}$ & \multicolumn{2}{|c|}{$\begin{array}{l}n \text { with levator } \\
\text { avulsion }\end{array}$} & $\begin{array}{l}\text { Percentage of } \\
\text { women of study } \\
\text { population with } \\
\text { levator avulsion }\end{array}$ & $\begin{array}{l}\text { Follow-up } \\
\text { duration }^{\mathrm{a}}\end{array}$ & Conclusion \\
\hline Dietz [32] & Complete & 29 & $35 \%$ & $\begin{array}{r}4.5 \text { years } \\
{[3-6.4]}\end{array}$ & $\begin{array}{l}\text { Complete avulsion was } \\
\text { associated with an RR of } \\
3 \text { to } 4 \text { for cystocele recurrence }\end{array}$ \\
\hline $\begin{array}{c}\text { Model } \\
{[34]}\end{array}$ & Complete & 156 & $21 \%$ & NR & $\begin{array}{l}\text { Complete avulsion was } \\
\text { associated with an increased } \\
\text { prevalence of significant } \\
\text { POP and symptoms of POP } \\
\text { after previous POP or } \\
\text { anti- incontinence surgery }\end{array}$ \\
\hline $\begin{array}{c}\text { Morgan } \\
{[28]}\end{array}$ & Major & 46 & $55 \%$ & $\begin{array}{l}42.3 \text { days } \\
(12.0)\end{array}$ & $\begin{array}{l}\text { Women with major avulsions } \\
\text { were less likely to have anterior } \\
\text { compartment support at least } \\
2 \mathrm{~cm} \text { above the hymen after } \\
\text { surgery compared to women } \\
\text { with no or minor avulsions }\end{array}$ \\
\hline \multirow{2}{*}{$\begin{array}{l}\text { Weemhoff } \\
\text { [35] }\end{array}$} & Partial & 59 & $39 \%$ & \multirow{2}{*}{$\begin{array}{c}31 \text { months } \\
{[14-50]}\end{array}$} & \multirow{2}{*}{$\begin{array}{l}\text { Fifty-two percent of women } \\
\text { with anatomical recurrence of } \\
\text { cystocele had a complete } \\
\text { avulsion compared to } 31 \% \text { of } \\
\text { women without anatomical } \\
\text { recurrence. There was no } \\
\text { difference in anatomical } \\
\text { recurrence in relation to partial } \\
\text { avulsion }\end{array}$} \\
\hline & Complete & 63 & $41 \%$ & & \\
\hline $\begin{array}{l}\text { Wong }^{\mathrm{b}} \\
{[37]}\end{array}$ & Complete & 83 & $38 \%$ & $\begin{array}{l}2.1 \text { years } \\
{[6 \text { weeks- }} \\
5.6 \text { years }]\end{array}$ & $\begin{array}{l}\text { Complete avulsion was associated } \\
\text { with an OR of } 2.27 \text { ( } 95 \% \text { CI } \\
1.23-4.21) \text { for significant } \\
\text { cystocele recurrence on } \\
\text { ultrasound. This effect was } \\
\text { significant for women after a } \\
\text { specific type of mesh operation }\end{array}$ \\
\hline
\end{tabular}

POP pelvic organ prolapse, $n$ number of patients, $S D$ standard deviation, $N R$ not reported, $R R$ relative risk, $O R$ odds ratio, $95 \%$ CI $95 \%$ confidence interval

${ }^{\mathrm{a}}$ Median [range] or mean (SD)

${ }^{\mathrm{b}}$ Conference abstract, (so far) no full text article available a supposedly intact contralateral side hereby making bilateral defects much more difficult to detect digitally than on imaging. Overall, it seems that even though palpation of the muscle defect appears to be the easiest diagnostic method to implement in routine clinical care, the value of this method is limited. Implementation of either perineal ultrasonography or MR imaging in the diagnostic workup of women with complaints of pelvic floor dysfunction appears more feasible and of added value.

\section{Conclusion}

In conclusion, a clear relation exists between visualized pubovisceral avulsions and POP stage and symptoms of POP. Recurrence rates after POP surgery were also reported to be higher among women with this prevalent anatomical defect. The association between pubovisceral avulsions and urinary symptoms, and symptoms of anorectal dysfunction, was less apparent. 
Acknowledgement The authors thank Elmie Peters, senior librarian at the University Library of the Medical Sciences Department of the Radboud University Nijmegen, for her assistance and expertise in developing a systematic research strategy.

\section{Conflicts of interest None.}

Open Access This article is distributed under the terms of the Creative Commons Attribution License which permits any use, distribution, and reproduction in any medium, provided the original author(s) and the source are credited.

\section{Appendix 1: full PubMed literature search terms}

$((((()((($ magnetic resonance imaging $))$ OR ("MR imaging")) OR ("MR studies")) OR ("MR study")) OR (MRI))) OR (((()(((ultrasonography)) OR (ultrasonograph*)) OR (ultrasonic imaging)) OR (echograph*)) OR (sonograph*)) OR (ultrasound)) OR (echo))) OR (((((physical examination)) OR (palpation)) OR (digital detection)) OR (medical examination)))) AND (((((((pelvic floor)) OR (levator ani)) OR (pubovisc*)) OR (pubococ*)) OR (puborect*)) OR (puboperine*))

\section{Appendix 2: full Embase literature search terms}

((exp nuclear magnetic resonance imaging/ or (magnetic and resonance and imaging) or (MR stud*) or MRI) OR (exp echography/ or ultrasonic imaging or ultrasound or ultrasonograph* or echograph* or sonograph* or echo) OR (exp physical examination/ or exp medical examination/ or digital detection or palpation or physical examination or medical examination)) AND (exp levator ani muscle/ or levator ani or pelvic floor or pelvis floor or pubovisc* or puborect* or pubococ* or puboperine*)

\section{Appendix 3: full CINAHL literature search terms}

((MH "Magnetic Resonance Imaging" or (magnetic and resonance and imaging) or MRI or MR Imaging or MR studies or MR study or MR stud*) or (MH "Ultrasonography + " or ultrasonography or ultrasound or echo or ultrasonic imaging or ultrasonograph* or sonograph* or echograph*) or (MH "Physical Examination + " or physical examination or medical examination or palpation or digital detection)) and (MH "Pelvic Floor Muscles" or levator ani or pelvic floor or pelvis floor or pubovisc* or pubococ* or puborect*)

\section{References}

1. Digesu GA, Chaliha C, Salvatore S, Hutchings A, Khullar V (2005) The relationship of vaginal prolapse severity to symptoms and quality of life. BJOG 112(7):971-976

2. Olsen AL, Smith VJ, Bergstrom JO, Colling JC, Clark AL (1997) Epidemiology of surgically managed pelvic organ prolapse and urinary incontinence. Obstet Gynecol 89(4):501-506

3. Fialkow MF, Newton KM, Lentz GM, Weiss NS (2008) Lifetime risk of surgical management for pelvic organ prolapse or urinary incontinence. Int Urogynecol J Pelvic Floor Dysfunct 19(3):437-440

4. Smith FJ, Holman CD, Moorin RE, Tsokos N (2010) Lifetime risk of undergoing surgery for pelvic organ prolapse. Obstet Gynecol 116(5):1096-1100

5. de Boer TA, Slieker-Ten Hove MC, Burger CW, Kluivers KB, Vierhout ME (2011) The prevalence and factors associated with previous surgery for pelvic organ prolapse and/or urinary incontinence in a cross-sectional study in The Netherlands. Eur J Obstet Gynecol Reprod Biol 158(2):343-349

6. Grody MH (1998) Urinary incontinence and concomitant prolapse. Clin Obstet Gynecol 41(3):777-785

7. Salvatore S, Siesto G, Serati M (2010) Risk factors for recurrence of genital prolapse. Curr Opin Obstet Gynecol 22(5):420-424

8. Chiaffarino F, Chatenoud L, Dindelli M, Meschia M, Buonaguidi A, Amicarelli F et al (1999) Reproductive factors, family history, occupation and risk of urogenital prolapse. Eur J Obstet Gynecol Reprod Biol 82(1):63-67

9. Shek KL, Dietz HP (2010) Intrapartum risk factors for levator trauma. BJOG 117(12):1485-1492

10. Krofta L, Otcenásek M, Kasiková E, Feyereis1 J (2009) Pubococcygeus-puborectalis trauma after forceps delivery: evaluation of the levator ani muscle with 3D/4D ultrasound. Int Urogynecol J Pelvic Floor Dysfunct 20(10):1175-1181

11. Kearney R, Fitzpatrick M, Brennan S, Behan M, Miller J, Keane D et al (2010) Levator ani injury in primiparous women with forceps delivery for fetal distress, forceps for second stage arrest, and spontaneous delivery. Int $\mathrm{J}$ Gynaecol Obstet 111(1):19-22

12. Valsky DV, Lipschuetz M, Bord A, Eldar I, Messing B, HochnerCelnikier D et al (2009) Fetal head circumference and length of second stage of labor are risk factors for levator ani muscle injury, diagnosed by 3-dimensional transperineal ultrasound in primiparous women. Am J Obstet Gynecol 201(1):91.e1-91.e7

13. DeLancey JO, Morgan DM, Fenner DE, Kearney R, Guire K, Miller JM et al (2007) Comparison of levator ani muscle defects and function in women with and without pelvic organ prolapse. Obstet Gynecol 109(2 Pt 1):295-302

14. Dietz HP, Simpson JM (2008) Levator trauma is associated with pelvic organ prolapse. BJOG 115(8):979-984

15. DeLancey JO, Kearney R, Chou Q, Speights S, Binno S (2003) The appearance of levator ani muscle abnormalities in magnetic resonance images after vaginal delivery. Obstet Gynecol 101 (1):46-53

16. Dietz HP, Lanzarone V (2005) Levator trauma after vaginal delivery. Obstet Gynecol 106(4):707-712

17. Dietz HP, Steensma AB (2006) The prevalence of major abnormalities of the levator ani in urogynaecological patients. BJOG 113 (2):225-230

18. Dietz HP (2004) Ultrasound imaging of the pelvic floor. Part II: three-dimensional or volume imaging. Ultrasound Obstet Gynecol 23(6):615-625

19. Bump RC, Mattiasson A, Bø K, Brubaker LP, DeLancey JO, Klarskov $P$ et al (1996) The standardization of terminology of 
female pelvic organ prolapse and pelvic floor dysfunction. Am J Obstet Gynecol 175(1):10-17

20. Kearney R, Miller JM, Ashton-Miller JA, DeLancey JO (2006) Obstetric factors associated with levator ani muscle injury after vaginal birth. Obstet Gynecol 107(1):144-149

21. Dietz HP, Shek KL (2009) Tomographic ultrasound imaging of the pelvic floor: which levels matter most? Ultrasound Obstet Gynecol 33(6):698-703

22. Dietz HP, Bernardo MJ, Kirby A, Shek KL (2011) Minimal criteria for the diagnosis of avulsion of the puborectalis muscle by tomographic ultrasound. Int Urogynecol J 22(6):699-704

23. Adekanmi OA, Freeman RM, Jackson S, Puckett M, Papapanos P (2003) Prevalence of pubococcygeus muscle detachment from the pubic bone in women with symptomatic anterior vaginal compartment prolapse. J Pelvic Med Surg 9(4):173-177

24. Heilbrun ME, Nygaard IE, Lockhart ME, Richter HE, Brown MB, Kenton KS et al (2010) Correlation between levator ani muscle injuries on magnetic resonance imaging and fecal incontinence, pelvic organ prolapse, and urinary incontinence in primiparous women. Am J Obstet Gynecol 202(5):488.e1-488.e6

25. Lewicky-Gaupp C, Brincat C, Yousuf A, Patel DA, DeLancey JO, Fenner DE (2010) Fecal incontinence in older women: are levator ani defects a factor? Am J Obstet Gynecol 202(5):491.e1-491.e6

26. Morgan DM, Cardoza P, Guire K, Fenner DE, DeLancey JO (2010) Levator ani defect status and lower urinary tract symptoms in women with pelvic organ prolapse. Int Urogynecol J 21(1):47-52

27. Morgan DM, DeLancey JO, Guire KE, Fenner DE (2007) Symptoms of anal incontinence and difficult defecation among women with prolapse and a matched control cohort. Am J Obstet Gynecol 197(5):509.e1-509.e6

28. Morgan DM, Larson K, Lewicky-Gaupp C, Fenner DE, Delancey JO (2011) Vaginal support as determined by levator ani defect status 6 weeks after primary surgery for pelvic organ prolapse. Int J Gynaecol Obstet 114(2):141-144

29. Abdool Z, Shek KL, Dietz HP (2009) The effect of levator avulsion on hiatal dimension and function. Am J Obstet Gynecol 201 (1):89.e1-89.e5

30. Chantarasorn V, Shek KL, Dietz HP (2011) Sonographic detection of puborectalis muscle avulsion is not associated with anal incontinence. Aust N Z J Obstet Gynaecol 51(2):130-135

31. Dietz HP (2007) Quantification of major morphological abnormalities of the levator ani. Ultrasound Obstet Gynecol 29(3):329-334

32. Dietz HP, Chantarasorn V, Shek KL (2010) Levator avulsion is a risk factor for cystocele recurrence. Ultrasound Obstet Gynecol 36(1):76-80

33. Dietz HP, Kirby A, Shek KL, Bedwell PJ (2009) Does avulsion of the puborectalis muscle affect bladder function? Int Urogynecol $\mathrm{J}$ Pelvic Floor Dysfunct 20(8):967-972

34. Model AN, Shek KL, Dietz HP (2010) Levator defects are associated with prolapse after pelvic floor surgery. Eur J Obstet Gynecol Reprod Biol 153(2):220-223

35. Weemhoff M, Vergeldt TF, Notten K, Serroyen J, Kampschoer PH, Roumen FJ (2012) Avulsion of puborectalis muscle and other risk factors for cystocele recurrence: a 2-year follow-up study. Int Urogynecol J 23(1)65-71

36. Rodrigo N, Shek KL, Dietz HP (2011) Rectal intussusception is associated with abnormal levator ani muscle structure and morphometry. Tech Coloproctol 15(1):39-43
37. Wong V, Shek KL, Rane A, Goh J, Dietz HP (2011) Is levator avulsion a predictor for cystocele recurrence following anterior vaginal mesh? Neurourology and Urodynamics Conference: $41 \mathrm{st}$ Annual Meeting of the International Continence Society. ICS 30 (6): $879-880$

38. Dietz HP, Shek C (2008) Validity and reproducibility of the digital detection of levator trauma. Int Urogynecol J Pelvic Floor Dysfunct 19(8):1097-1101

39. Dietz HP, Hyland G, Hay-Smith J (2006) The assessment of levator trauma: a comparison between palpation and $4 \mathrm{D}$ pelvic floor ultrasound. Neurourol Urodyn 25(5):424-427

40. Kearney R, Miller JM, DeLancey JO (2006) Interrater reliability and physical examination of the pubovisceral portion of the levator ani muscle, validity comparisons using MR imaging. Neurourol Urodyn 25(1):50-54

41. Zhuang RR, Song YF, Chen ZQ, Ma M, Huang HJ, Chen JH et al (2011) Levator avulsion using a tomographic ultrasound and magnetic resonance-based model. Am J Obstet Gynecol 205 (3):232.e1-232.e8

42. Allen RE, Hosker GL, Smith AR, Warrell DW (1990) Pelvic floor damage and childbirth: a neurophysiological study. Br J Obstet Gynaecol 97(9):770-779

43. Snooks SJ, Setchell M, Swash M, Henry MM (1984) Injury to innervation of pelvic floor sphincter musculature in childbirth. Lancet 2(8402):546-550

44. Chou Q, DeLancey JO (2001) A structured system to evaluate urethral support anatomy in magnetic resonance images. Am J Obstet Gynecol 185(1):44-50

45. Kearney R, Sawhney R, DeLancey JO (2004) Levator ani muscle anatomy evaluated by origin-insertion pairs. Obstet Gynecol 104 (1):168-173

46. Adekanmi OA, Freeman RM, Jackson SA, Puckett M, Bombieri L, Waterfield MR (2009) Do the anatomical defects associated with cystocele affect the outcome of the anterior repair? A clinical and radiological study. Int Urogynecol J Pelvic Floor Dysfunct 20 (11):1369-1377

47. Dietz HP (2011) Pelvic floor ultrasound in prolapse: what's in it for the surgeon? Int Urogynecol J 22(10):1221-1232

48. Dietz HP (2007) Levator trauma in labor: a challenge for obstetricians, surgeons and sonologists. Ultrasound Obstet Gynecol 29 (4):368-371

49. Notten KJ, Weemhoff M, Kluivers KB, Schweitzer KJ, Mulder F, Stoker J et al (2011) Protocol for translabial 3D-ultrasonography for diagnosing levator defects (TRUDIL): a multicentre cohort study for estimating the diagnostic accuracy of translabial 3Dultrasonography of the pelvic floor as compared to MR imaging. BMC Womens Health 11:23

50. Patel DA, Xu X, Thomason AD, Ransom SB, Ivy JS, DeLancey JO (2006) Childbirth and pelvic floor dysfunction: an epidemiologic approach to the assessment of prevention opportunities at delivery. Am J Obstet Gynecol 195(1):23-28

51. Green TH Jr (1975) Urinary stress incontinence: differential diagnosis, pathophysiology, and management. Am J Obstet Gynecol 122(3):368-400

52. Shek KL, Pirpiris A, Dietz HP (2010) Does levator avulsion increase urethral mobility? Eur J Obstet Gynecol Reprod Biol 153(2):215-219 